\title{
THE KARST MANDHIP KHOL-PYTHON CAVE COMPLEX IN THE LENTICULAR LIMESTONE INTERCALATIONS OF THE METAMORPHIC CHHATRELA FORMATION (CHHATTISGARH, INDIA)
}

\author{
JAMSKI SPLET MANDHIP KHOL (PITONOVA JAMA) \\ V VKLJUČKIH LEČASTIH APNENCEV V METAMORFNI FORMACIJI \\ CHHATRELA (CHHATTISGARH, INDIJA)
}

\author{
Rosario RUGGIERI ${ }^{1} \&$ Jayant BISWAS ${ }^{2}$
}

\begin{abstract}
UDC 551.435.8(540)

Rosario Ruggieri \& Jayant Biswas: The Karst Mandhip Kholpython cave complex in the lenticular limestone intercalations of the matamorphic Chhatrela formation (Chhattisgarh, India)

The Mandhip Khol-Pyton cave, located in an area declared Protected Forest in the Rajnandgaon District about $7 \mathrm{~km}$ in a direct line WNW from the village of Thakurtola (N21 $39^{\prime}$ : E080 $58^{\prime}$ ), consists of an upper level orientated essentially along NE-SW and NNW-SSE fracture systems, subsequently connected through a NE-SW structure with an independent karst system, at a lower level orientated predominantly along bedding planes. The speleogenesis controlled by various structural elements has manifested itself as having different morphologies in the two levels. In fact, fracture-controlled vadose passages prevail in the upper level, while water flow along the bedding planes in the lower level has caused morphologies characterized by wide but low passages. The studied system constitutes a particular example of karst morphologies developed in a lenticular limestone formation within phyllite rocks of Precambrian metamorphic age.
\end{abstract}

Keywords: India, Chhattisgarh, karst, speleogenesis, Mandhip Khol.
Izvleček UDK 551.435.8(540)

Rosario Ruggieri \& Jayant Biswas: Jamski splet Mandhip Khol (Pitonova jama) $v$ vključkih lečastih apnencev $v$ metamorfni formaciji Chhatrela (Chhattisgarh, Indija)

Jamo Mandhip Khol (Pitonova jama), ki je na ozemlju »Zavarovanega gozda okrožja Rajnandgaon «, 7 km zračne črte ZSZ od vasi Thakurtola (210 39’ S:800 58’ V), sestavlja zgornji del, $\mathrm{v}$ glavnem usmerjen vzdolž prelomnih sistemov SV-JZ in SSZJJV, povezan s strukturo v smeri SV-JZ z neodvisnim kraškim sistemom, medtem ko je spodnji del usmerjen pretežno vzdolž plasti. Speleogeneza je odvisna od različnih strukturnih elementov, kar se kaže v različni morfologiji obeh delov. V zgornjem delu prevladujejo vadozni rovi vzdolž razpok, medtem ko je v spodnjem delu jame vodni tok izoblikoval široke in nizke rove vzdolž plasti. Preučevani jamski splet je lep primer kraških oblik, razvitih v lečastih apnencih znotraj filitnih kamnin predkambrijske starosti.

Ključne besede: Indija, Chhattisgarh, kras, speleogeneza, Mandhip Khol.

\section{BACKGROUND}

In December 2007 the Ragusa CIRS, invited by and, in cooperation with the National Cave Research \& Protection Organization of Raipur (Chhattisgarh State, India), carried out explorative and morphological studies of the caves complex comprised of Mandhip Khol and Python cave. The cave system lies about $7 \mathrm{~km}$ in a direct line approximately west-north-west from the village of Thakur-

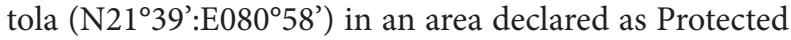

\footnotetext{
${ }^{1}$ Centro Ibleo di Ricerche Speleo-Idrogeologiche, Ragusa, Italy, email:info@cirs-ragusa.org

${ }^{2}$ National Cave Research \& Protection Organization, Central Zone, Raipur, C.G. India, email: dr.jayant@yahoo.com

Received/Prejeto: 9.9.2010
} 


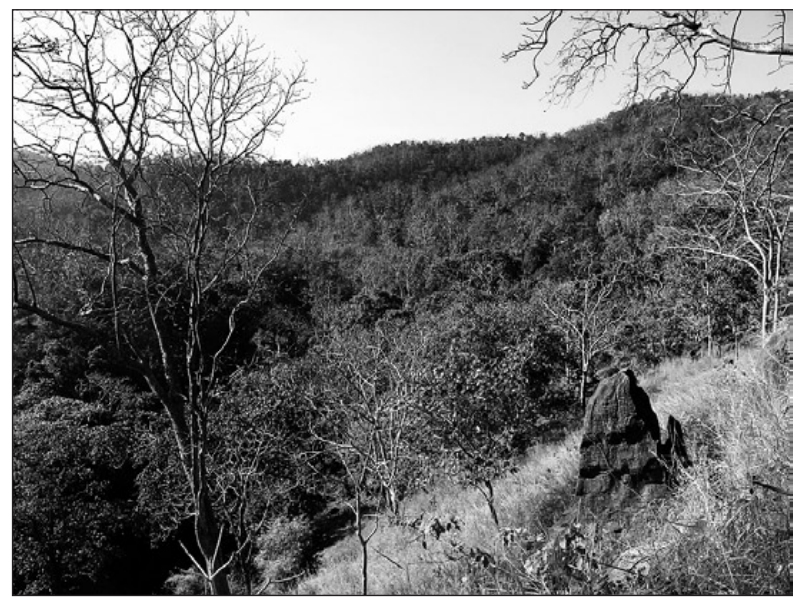

Fig. 1: Area of research (from Gebauer 2007, modified).

Forest in the Rajnandgaon District of the Indian Union State of Chhattisgarh. In this area various surface (Fig. 1) and subterranean karst morphologies have been observed. The subterranean forms originated along the bedding planes of the limestone layers (Fig. 2).

Karst studies in this region are very limited. Besides, the short permanence in the area of research for safety reasons, has not allowed the definition of an exhaustive geological and hydrological context concerning the ex-

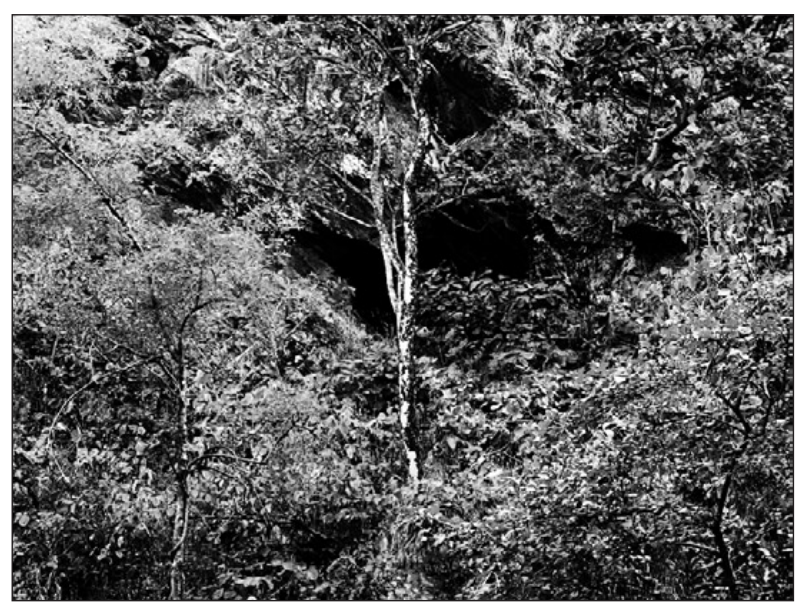

Fig. 2: Cave developed along the limestone bedding plane of the river bank (Photo: $R$. Ruggieri).

plored karst system. However, useful data have been obtained by the geomorphological survey, both outside and inside the caves, and by the geostructural survey carried out after the explorative phase.

This paper presents the topographical results of the surveys as well as the morphological/structural aspects on the basis of which some speleogenetic considerations were derived.

\section{GEOGRAPHICAL AND GEOLOGICAL SITUATION}

Two karst caves, at a short distance from each other, are located at about $7 \mathrm{~km}$ from the Tokurtola village, in the Rajnandgaon district (State of Chhattisgarh, India) (Gebauer 2007). Mandhip Khol, the larger of the two caves, is characterized by two levels of galleries, of which the upper is, in parts, active during the rainy season (monsoon); the smaller cave, named Python Cave, contains a perennial stream, the Swet Ganga, which resurges in the upper reaches of the Seonath River valley.

Mandhip Khol, of which the entrance lies $174 \mathrm{~m}$ in a direct line due north of the entrance of Python Cave (at a vertical range of $22 \mathrm{~m}$ about $987 \mathrm{~m}$ long) has three entrances: the main one is located at $528 \mathrm{~m}$ asl (WGS 84, $21^{\circ} 40^{\prime} 24,16^{\prime \prime} \mathrm{N}-80^{\circ} 54^{\prime} 08,76^{\prime \prime} \mathrm{E}$ ); a second entrance is found at very short distance from the main one; the third entrance is located at $529 \mathrm{~m}$ asl $\left(21^{\circ} 40^{\prime} 18,03^{\prime \prime} \mathrm{N}-80^{\circ}\right.$ $54^{\prime} 10,20^{\prime \prime}$ E). The Python Cave extends for $119 \mathrm{~m}$, with $5 \mathrm{~m}$ overall difference in level, $511 \mathrm{~m}$ asl ( $21^{\circ} 40^{\prime} 17,80^{\prime \prime}$ $\left.\mathrm{N}-80^{\circ} 54^{\prime} 8,46 \mathrm{E}\right)$. The two caves are separated by a little less than $20 \mathrm{~m}$ long sump. Combined, they constitute a single $1,030 \mathrm{~m}$ long cave system karst with a vertical range of $23 \mathrm{~m}$.
The above described caves have developed in the Limestone Member of the Chhatrela Formation belonging the Chilpi Group of Precambrian Age. This limestone occurs as a lenticular structure interbedded in phyllite layers also containing sandstone layers (Choubey 1999).

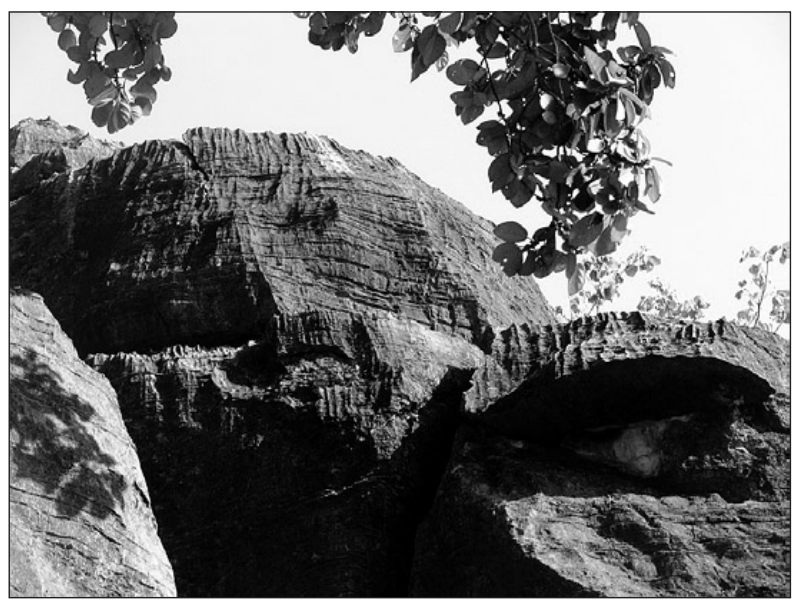

Fig. 3: Karren morphologies in the grey coloured stromatolitic limestone of Precambrian age (Photo: R. Ruggieri). 
A wide variety of karren have been observed on the exposed, grey coloured, surface of the in stromatolithic limestone (Fig. 3). Two main fracture systems have been recognised NE-SW and NNW-SSE, both dipping about $80^{\circ}$ toward the west. The main galleries develop along these systems, while a secondary system E-W crosses the bedding planes in the lower level of the cave. In the Python Cave the main gallery develops along the limestone bedding planes with strike N-S and dip $47^{\circ}$ west.

\section{CAVE MORPHOLOGY AND SPELEOGENESIS}

The caves show a series of morphologies which indicate the various speleogenetic phases that the karst system has undergone. The morphologies and deposits in the system, listed in Tabs. 1 and 2, can be described as follows.

\section{UPPER LEVEL}

The cave system's upper level consists of walking sized and NE-SW and NNW-SSE trending cave passages (see Fig. 16 - cave map, parts 2-3-4), which are intersected by NE-SW trending low passages and NW sloping bedding plane passages (cave map, part 2). On the surfaces of these high passages there are morphologies of corrosion/erosion, such as cupola vaults resulting from turbulent water flow (Slabe 1995) during flood phases (monsoon period) and notches associated with prolonged periods of stationary level of vadose circu-

Tab. 1: Mandhip Khol cave - Morphologic / structural / hydrology elements.

\begin{tabular}{|c|c|c|c|}
\hline Upper level (see map) & Structures & Morphology/deposits & Conduicts morphology \\
\hline (1) Entrance branch & NW-SE & Gravity debris / boulders & Passage \\
\hline (2) Narrow branch & NE-SW / bedding plane & $\begin{array}{l}\text { Phreatic morphologies / red clay } \\
\text { filling / forms of corrosion }\end{array}$ & Low passage / phreatic \\
\hline (3) Big branch & NE-SW / dip 75 W & $\begin{array}{l}\text { Cupola of corrosion / white partly } \\
\text { corroded rimstone pools }\end{array}$ & Rift passage \\
\hline (4) Big branch & NNW-SSE / dip. 80 W & Cupola of corrosion & Passage / gorge \\
\hline (5) Branch of collapsing & NNW-SSE & grooves/ collapsed debris & Passage / chamber \\
\hline (6) Crawling branch & Bedding plane & Debris & Low passage \\
\hline \multicolumn{4}{|l|}{ Right Lower level } \\
\hline (7) Right shaft branch & Fratcture NE-SW & Vadose / detritic deposits & Rift passage / gorge \\
\hline (8) Stream passage & $\begin{array}{l}\text { Bedding plane / with } \\
\text { transversal fracture E-W }\end{array}$ & $\begin{array}{l}\text { (left) wall red clay / conglomerate } \\
\text { on / basin with water / ceiling } \\
\text { channels / vadose erosion on } \\
\text { detritic deposits }\end{array}$ & Low passage \\
\hline (9) Pool-sump & Bedding plane & & Low passage \\
\hline (10) Collapse chamber & Clastic-gravitative & Big clastic rocks / boulders & Ascending chamber \\
\hline (11) High branch & $\begin{array}{l}\text { Contact bedding plane } \\
\text { limestone/schist }\end{array}$ & $\begin{array}{l}\text { Phreatic / clastic-gravitative / } \\
\text { calcitic deposits }\end{array}$ & Conduit \\
\hline (12) High branch & Bedding plane & $\begin{array}{l}\text { Phreatic conduit with clay } \\
\text { filling and flat ceiling due to } \\
\text { antigravitative erosion }\end{array}$ & Low passage \\
\hline (13) High branch discending & Bedding plane / fracture & $\begin{array}{l}\text { Phreatic conduit / vadose channel } \\
\text { cut on red clay / leopard skin type } \\
\text { deposits and pendents }\end{array}$ & $\begin{array}{l}\text { Narrow gorge carved on } \\
\text { a red clay deposit }\end{array}$ \\
\hline \multicolumn{4}{|l|}{ Left lower level } \\
\hline (14) Left shaft branch & Fracture NE-SW & Vadose / detrital deposits & Passage/ gorge \\
\hline (15) Narrow conduct & Bedding plane & Detrital deposits & Narrow conduit \\
\hline (16) Chamber of arrows & Bedding p. / fracture & Tilted pendants & Chamber \\
\hline
\end{tabular}


Tab. 2: Python cave - Morphologic / structural / hydrology elements.

\begin{tabular}{l|l|l|l}
\hline Python Cave (see map) & Structures & Morphology/deposits & Conduits/morphology \\
\hline (17) Main gallery & Bedding plane N 280/47 & $\begin{array}{l}\text { Right wall: calcite deposits/ } \\
\text { concretions / rimstones }\end{array}$ & Passage partially flooded \\
\hline (18) Right branch & Bedding plane/fracture & Rimstones / calcite deposits & Chamber/ Pool/sump \\
\hline (19) Left branch & Bedding plane / fracture & Phreatic forms /calcite deposits & Narrow conduit \\
\hline
\end{tabular}

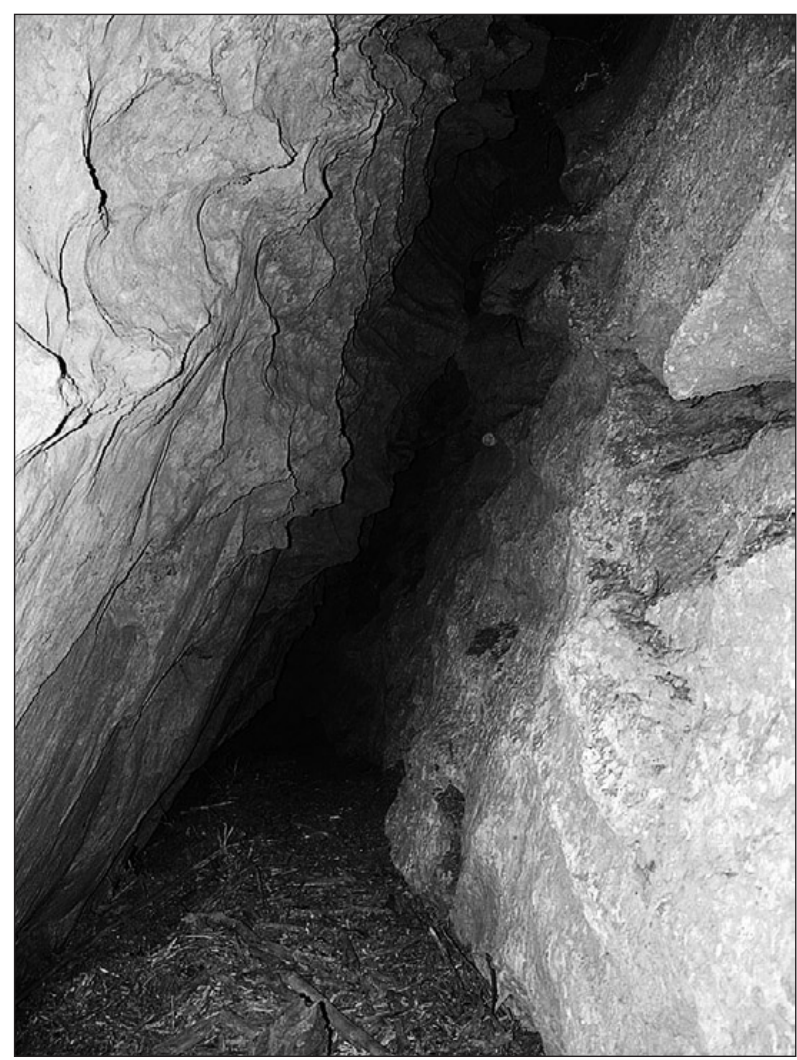

Fig. 4: Rift cave passage in the upper level controlled by NE-SW fracture (Photo: R. Ruggieri).

lation (Fig. 4). On the contrary, more typical morphologies of phreatic environment (polished surfaces and scallops) can be observed in the low but wide bedding planes passages partially infilled with red clay (Ford \& Williams 2007; Palmer 1991, 2007). Both features are morphologies inherited from past flooding events. The above mentioned morphologies point out a past upper circulation of the vadose type, along fracture passages, and a deeper circulation of the phreatic type, along the bedding planes. Such a circulation has afterwards deepened leaving deposits of the calcite type with formation of small rimstone pools on the walls of structural discontinuities and detrital fills in the low passages along the bedding planes (red clay).

Evidence of corrosion processes of calcite deposits on the walls of the passages are due to relatively recent phases associated with condensation of acidic water
(Dublyansky \& Dublyansky 1998; Dreybrodt et al. 2005; Badino 2004).

\section{LOWER LEVEL}

The cave system's lower level consists of mainly of low but wide bedding plane passages intersected by E-W trending fractures. Along these passages the presence of morphologies of both antigravitative or paragenetic erosion (Fig. 5) (Pasini 1973, 2009; Palmer 2007) and vadose channels (Fig. 6) points out cyclic filling up phases and subsequent emptying linked to the tectonic and climatic evolution of the region.

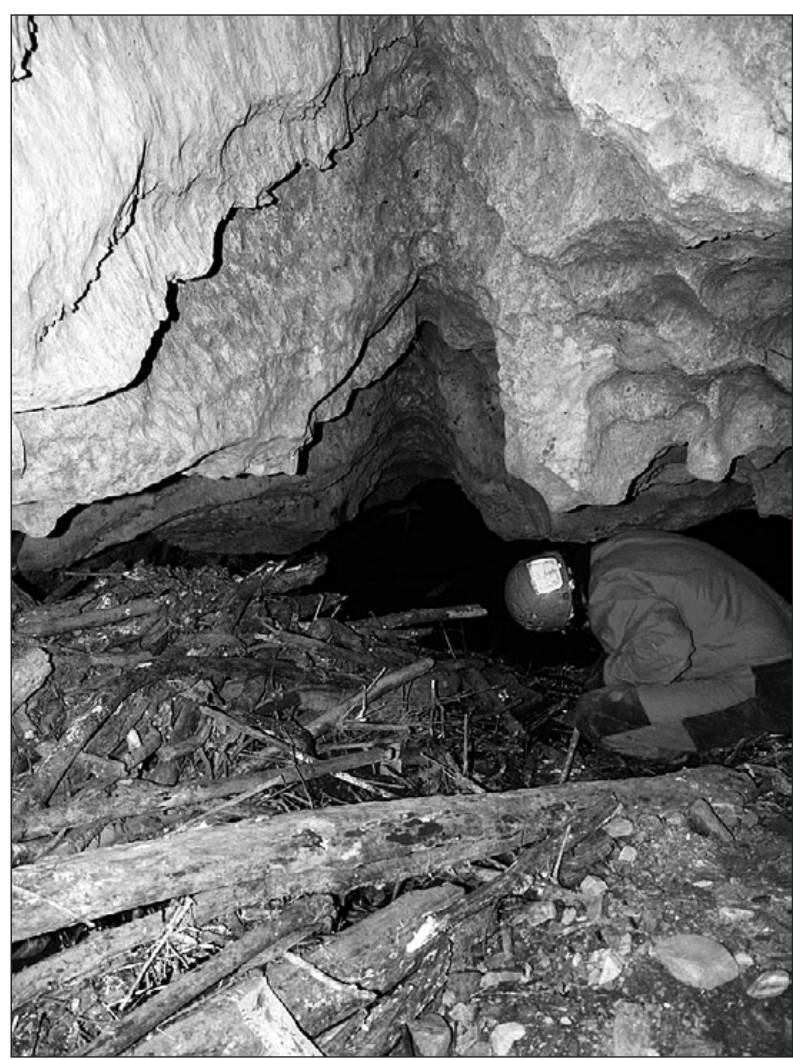

Fig. 5: Ceiling channel along fracture crossing the bedding plane of the lower cave level (Photo: R. Ruggieri).

In the lower level of the cave system, which is connected with the upper cave by a NE-SW trending rift (Fig. 7), are likewise evident collapse morphologies of large limestone blocks (intersection zones 


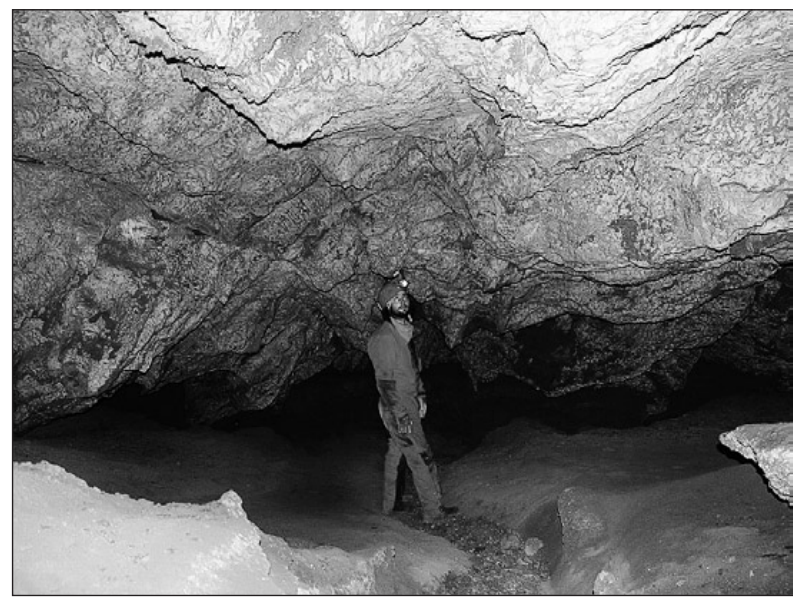

Fig. 6: Vadose corrosion forms in the dry streambed of the lower cave level (Photo: R. Ruggieri).

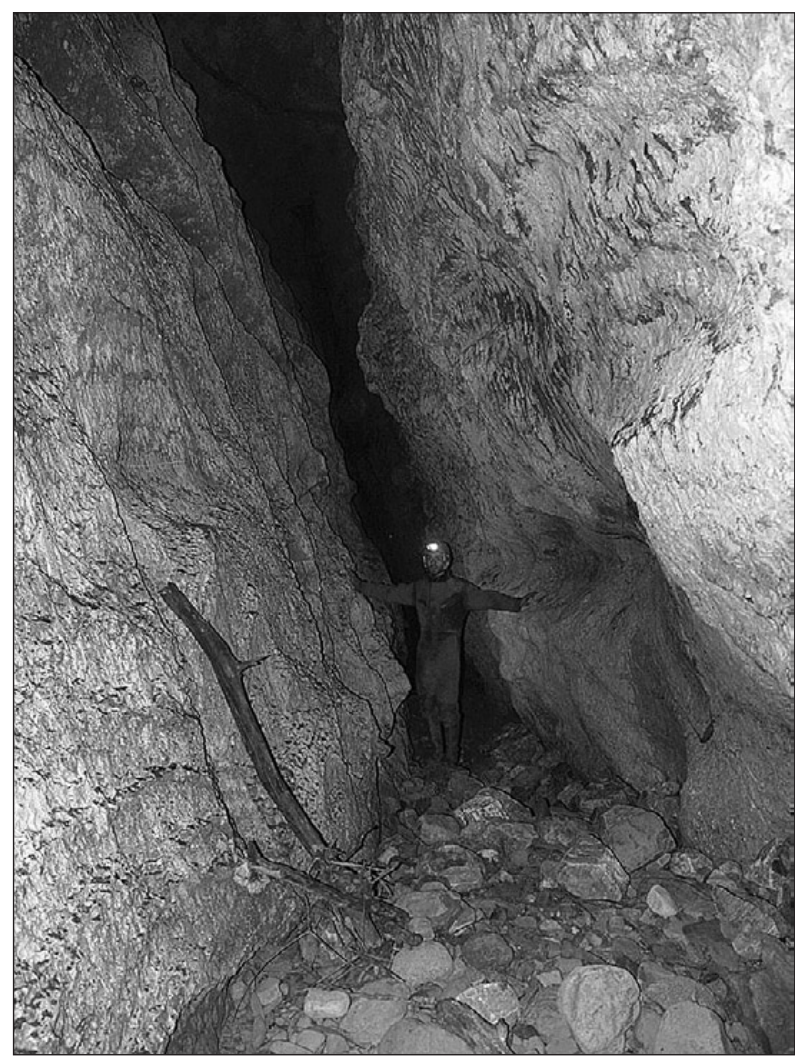

Fig. 7: Rift cave passage in the lower level along a NE-SW fracture (Photo: R. Ruggieri).

of several fractures) (Fig. 8) and remarkable fills of red clay along the stratigraphic contact between the metamorphic rocks and the karstified limestone (Fig. 9).

Also observable in the cave system's lower level are quite flat cave ceilings (Fig. 10), a typical morphologies derived from processes of antigravitative erosion to which are associated subsequent morphologies of va-

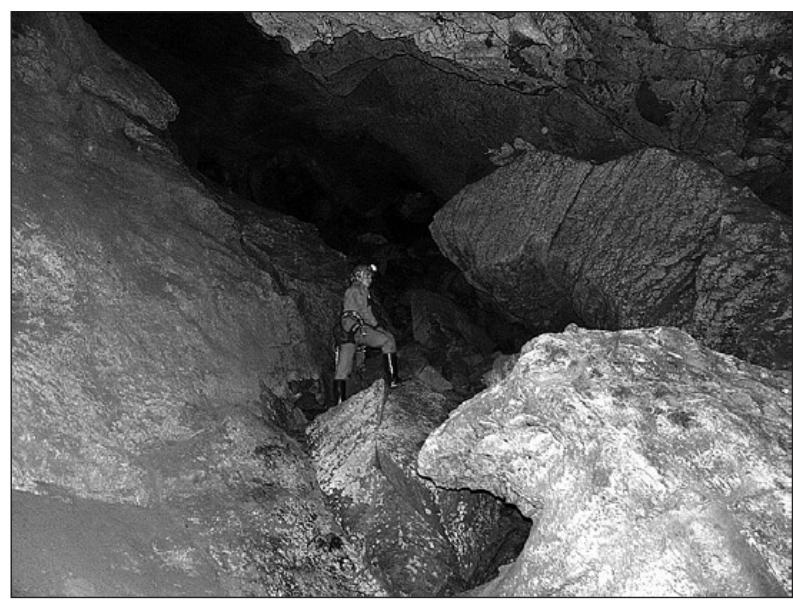

Fig. 8: Wide chamber with big collapsed boulders (Photo: R. Ruggieri).

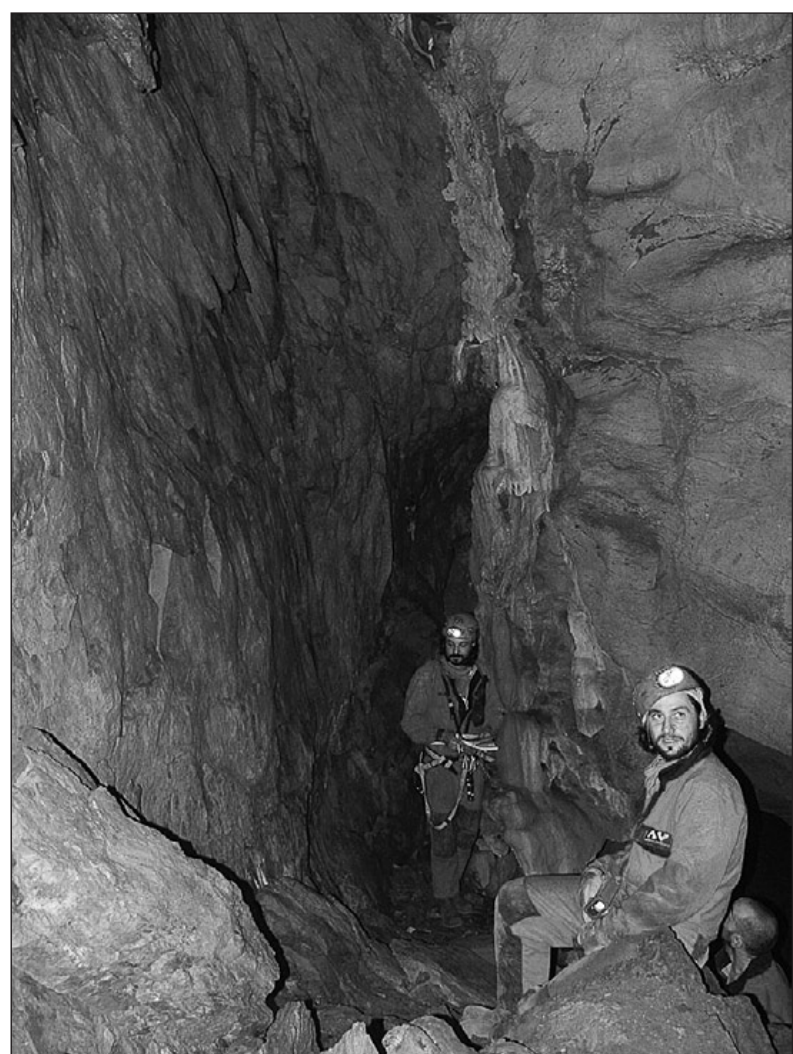

Fig. 9: To the left the schist wall of the cave opposite to the limestone right wall (Photo: R. Ruggieri).

dose flow indicated by small canyons carved in the red clay fills (Fig. 11).

The morphology of Python Cave (Fig. 12) is represented by a main bedding plane passage combined with smaller rift cave passages along fractures. A widespread calcite deposit with different forms (flowstones, micro-gours, stalactites, etc.) (Fig. 13) is present on the walls. The downstream part of the cave system, which 


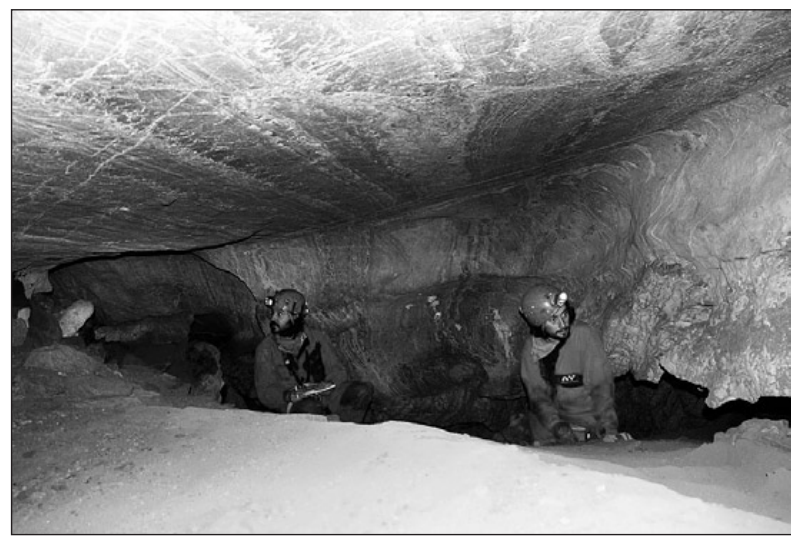

Fig. 10: Paragenetic environment of the cave (Photo: R. Ruggieri).

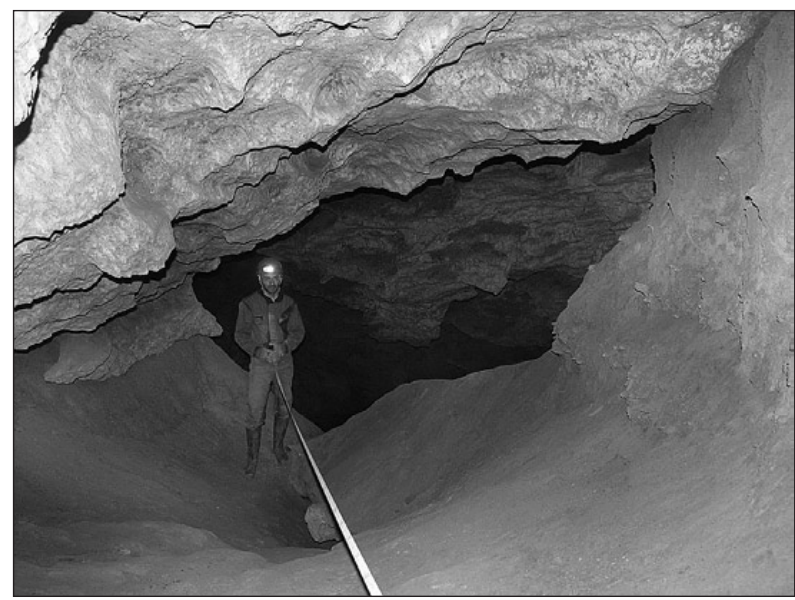

Fig. 11: Red canyon (Photo: R. Ruggieri).

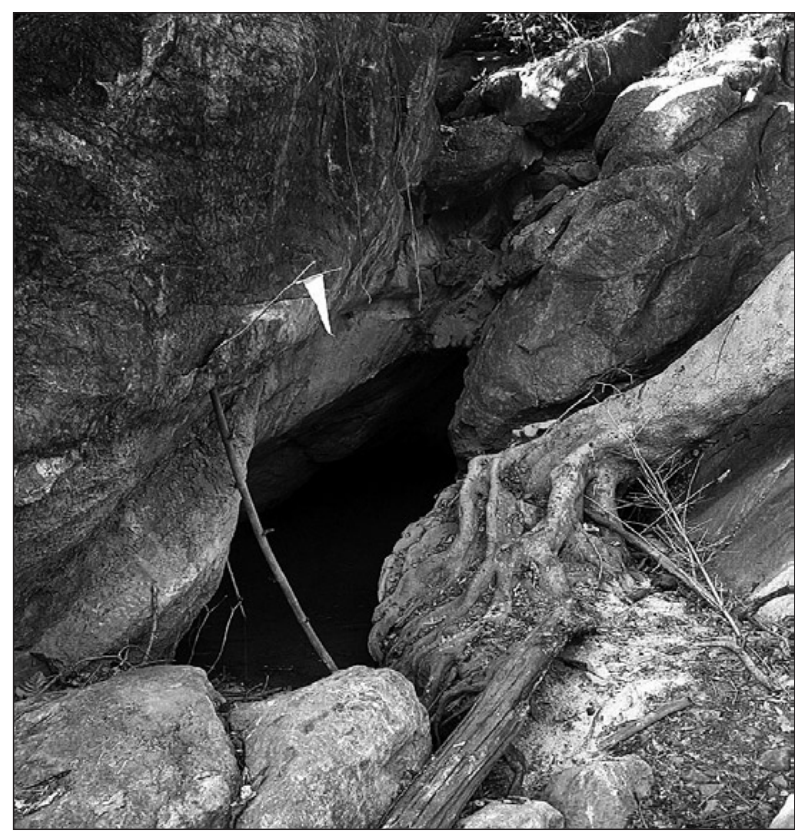

Fig. 12: Entrance of Python Cave developed along a bedding plane (Photo: R. Ruggieri).

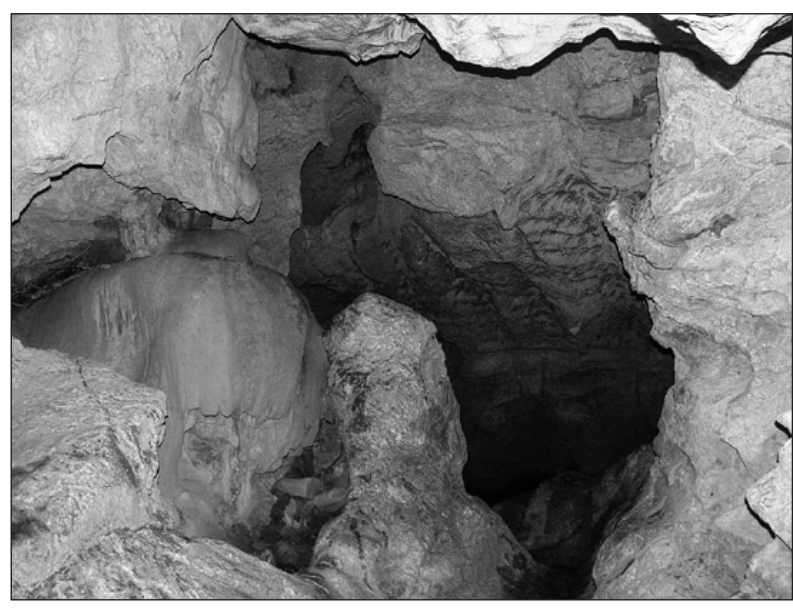

Fig. 13: Flowstone and passage forms of phreatic origin in the right branch of the Python Cave (Photo: R. Ruggieri).

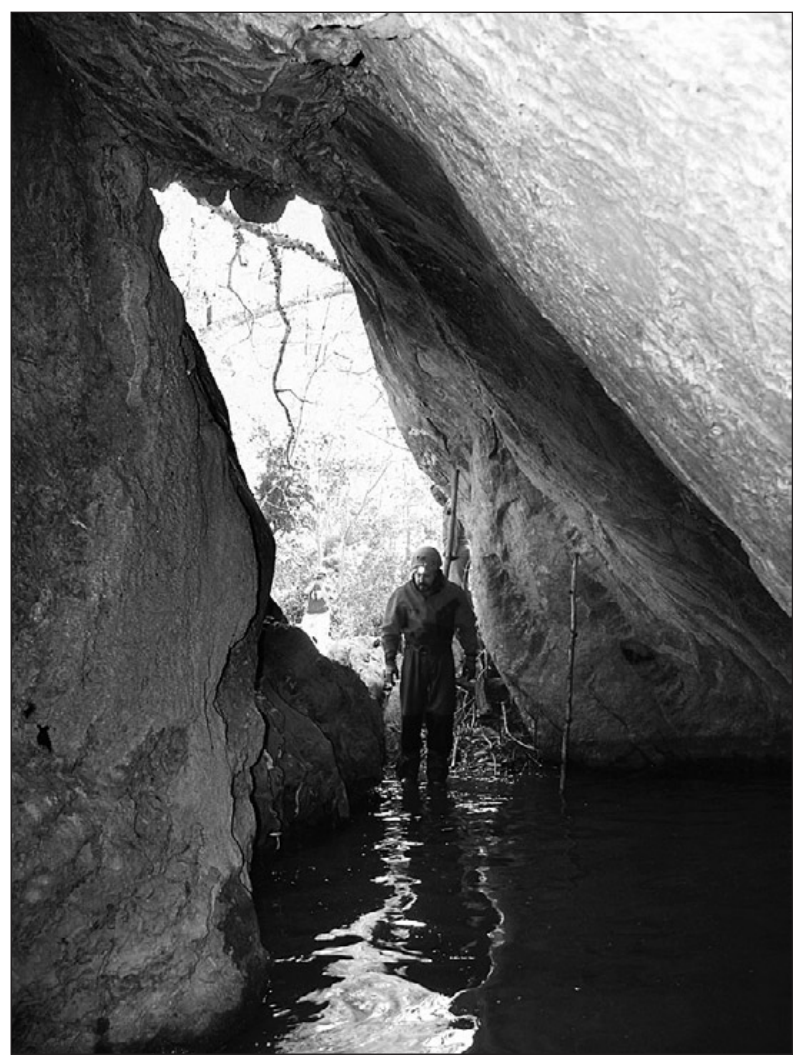

Fig. 14: Python Cave exsurgence entrance (Photo: R. Ruggieri).

is separated from the upstream part by a short slump, constitutes with its exsurgence the current base level of karst water circulating in the lenticular limestone occurrence intercalated in phyllites rocks of Precambrian age (Fig. 14).

Based on the detailed observations carried out in the cave system, the following speleogenetic phases are proposed for the two levels of the cave. 


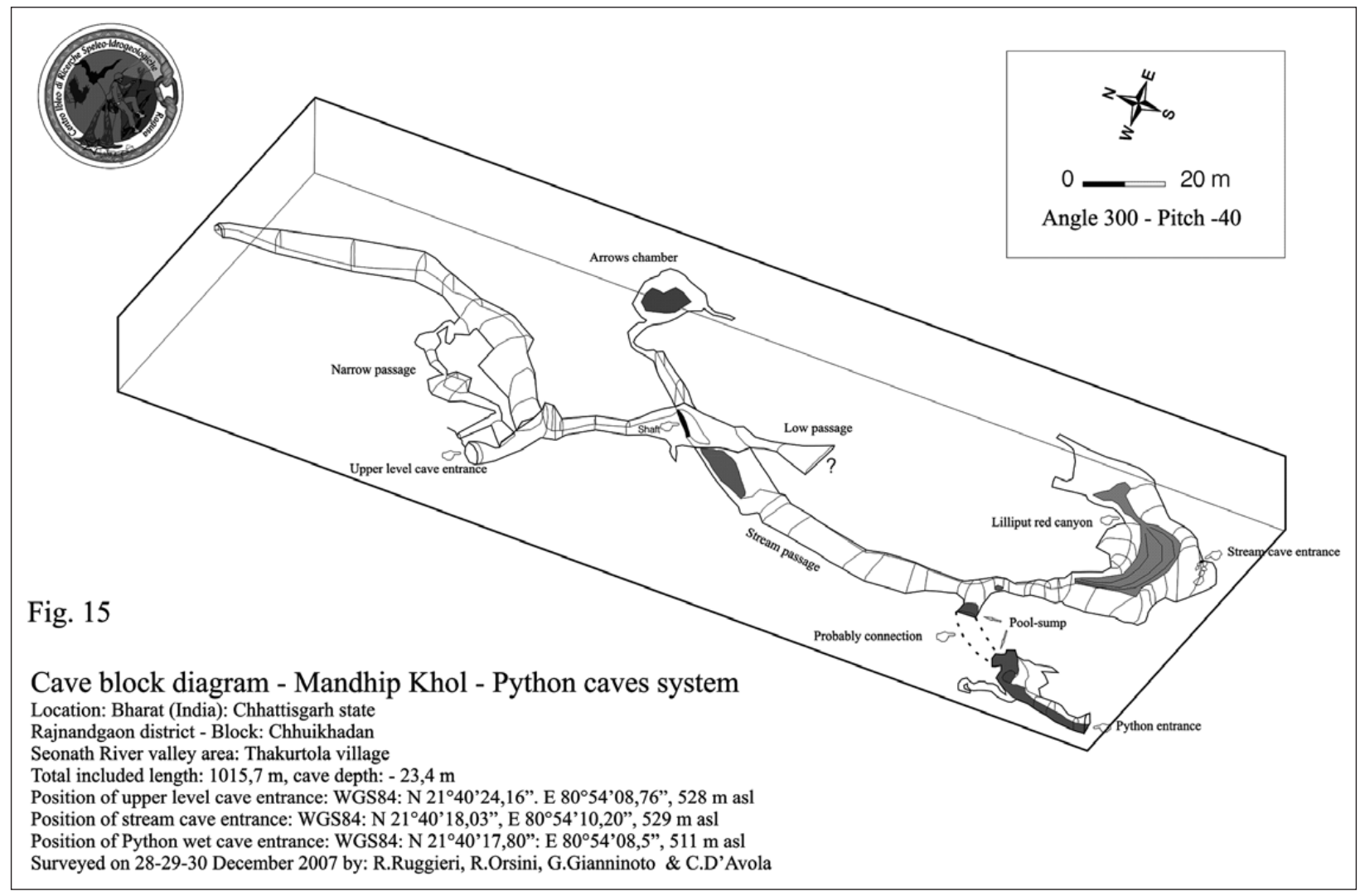

Fig. 15: Mandhip Khol and Python Cave block diagram.

\section{UPPER CAVE LEVEL}

Onset of karst processes in the upper level of the system by capturing the stream water through the NW-SE and NNW-SSE fracture systems. During this starting phase vadose passages with groove formation formed feeding a primitive network of phreatic conduits on bedding plane/fracture.

Further development of the system, by opening or reactivating of fractures (NE-SW), makes the upper level inactive. Speleothems start to develop in the passages while the phreatic passages tend to be filled with red soil. The opening of the fracture system NE-SW, besides causing the deepening of the karst circulation, puts the upper level in contact with the lower level determining in such a way a capture of the water flow.

\section{LOWER CAVE LEVEL}

The lower level, where the limestone-phyllite contact is observable, has experienced a different speleogenesis. The main high river passages developed along N-S bedding planes, while low passages morphologies formed where collapsing of layers occured.
A successive phase of filling seems indicated from the following elements: the eastern wall of the stream cave passage is coated by an apparently thick blanket of red clay that filled up a passage in the limestone/slate contact; the "ceiling channels" of the river branch and the flat morphology of the "ceiling" of the initial sector of the canyon, both likely formed by antigravitative erosion.

At last, a subsequent phase of rejuvenation is evidenced by the incision of the above mentioned canyon in its high branch and the incision of the conglomerate deposit that covers, during the dry phase, the stream flow coming to the surface through the Python Cave. This phase corresponds to the present conditions. 


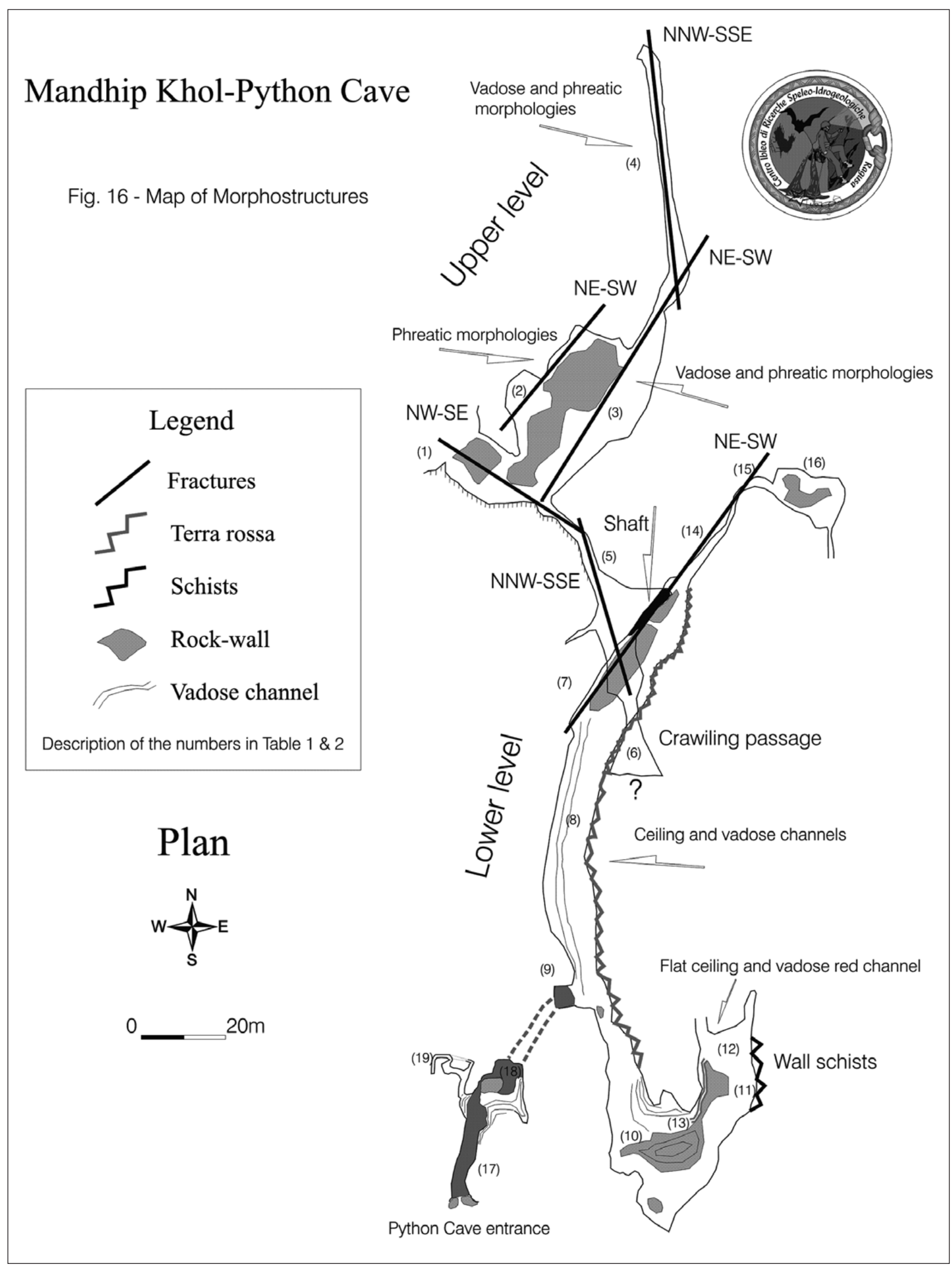

Fig. 16: Map Morphostructures. 


\section{CONCLUSIONS}

The two levels of the Mandhip Khol karst system, although they originated independently, are connected when the water sinking into the current main entrance flows downstream to the lower cave level. The abundant detritus, present in this lower level, consisting of both vegetable material (branches, leaves, etc.) and lithological deposits of various sizes (from argillaceous-sandy to decimetric pebbles) can be attributed to transport by water flushing down from the upper level. The opening and karstification of NE-SW fracture besides allowing such a connection, between the two levels, subsequently has caused, in fact, the progressive partial abandoning of the upper level, the water flow of which very likely was first drained toward south, on the outside, through the low bedding plane passage (part 6 of cave map), at a higher level compared to that of the current karst outcrop constituted by the Python Cave. This last one, finally, positioned along the direction of a bedding plane in the same way of the passages located upstream of it, from which it is separated by a sump little bit less than $20 \mathrm{~m}$ long, represents the natural outlet of the Mandhip Khol-Python Cave complex. Karst System which, from the hydrological point of view, drains the water captured from entrances of the upper level during the monsoon period, and the water circulating in the network of phreatic lower level conduits during the dry season.

\section{REFERENCES}

Badino, G., 2004: Clouds in Caves. Speleogenesis and Evolution of Karst Aquifers, 2, 2, 1-2.

Choubey, A., 1999: Regional geology and stratigraphy pp. 7-15, from PhD Thesis; title "Petrography and geochemistry of metasediments of Dongargarh Supergroup in Chhuikhadan-Saletekri areas, Rajnandgaon district" - Pt. Ravishankar Shukla University, Raipur India.

Dreybrodt, W., Gabrovšek, F. \& M. Perne, 2005: Condensation corrosion: a theoretical approach. Acta Carsologica, 34, 2, 317-348.

Dublyansky, V.N. \& Y.V. Dublyansky, 1998: The problem of condensation in Karst Studies. Journal of Cave and Karst Studies, 60, 1, 3-17.

Ford, D. C. \& P.W. Williams, 2007: Karst hydrogeology and geomorphology. John Wiley \& Sons, pp. 562, Chichester.
Gebauer, H.D., 2007: Mandhip Khol. Resources on the Speleology of Chhattisgarh State, India. Unpublished report, 1-2.

Palmer, A.N., 1991: Origin and morphology of limestone caves. Geol. S. Am. Bul., 103, 1-21.

Palmer, A.N., 2007: Cave Geology. Cave Books, pp. 454, Dayton, USA.

Pasini, G, 1973: Sull'importanza speleogenetica dell'erosione antigravitativa. Le Grotte d'Italia, 4, 297-326.

Pasini, G., 2009: A terminological matter: paragenesis antigravitative erosion or antigravitational erosion?International Journal of Speleology, 38, 2, 129-138.

Slabe, T., 1995: Cave Rocky Relief and its Speleogenetical significance. Karst Research Institute, Ljubljana, $120 \mathrm{pp}$. 